\title{
Pancasila as the cultural traits for Indonesian national religious identity in the era of globalization
}

\author{
Tatit Hariyanti \\ English Department, Universitas Teknologi Yogyakarta, Indonesia \\ Correspondence \\ Email: tatit.hariyanti@uty.ac.id
}

\begin{abstract}
This paper is library research attempting to explore the way to maintain the local identity in globalization for Indonesian particularly their national religious identity. Taking and tracking documents in the form of data relating to the issues of globalization, religious identity, and Pancasila and adopting the concept of grounded globalism by James L. Peacock which affirms and seeks embodied connectedness to locale, this paper shares the perspective that Pancasila is still qualified and deserve to be used as a basic foundation to maintain and strengthen the national religious identity of the Indonesian people in the global era. Indonesia does not need to be transformed by global identity. Indonesia has already had its own national religious identity which is global. The five principles of Pancasila need to be actualized as the ground and cultural traits of their global identity. By grounding global identity on Pancasila, Indonesians can enjoy globalization without losing its national identity.
\end{abstract}

Keywords: globalization, globalism, grounded, religious identity, Pancasila

$\begin{array}{llll}\text { Received: } & \text { Revised: } & \text { Accepted: } & \text { Published: } \\ \text { 14 September 2019 25 July 2020 } & \text { 25 August 2020 } & \text { 31 August 2020 }\end{array}$

\section{INTRODUCTION}

Globalization has been greeted with joy and fear associated with all localism: the state, nation and community. It has been widely acknowledged as the most powerful force that shapes the modern world. Some assert it inevitable and widely perceived as beyond human control, which further weakens resistance. It is regarded as a complex concept that is always connected with political, economic and socio-cultural aspects. Even though globalization may sometimes give rise to economic, political and cultural benefits it has been regarded as a serious threat. Culturally, globalization is often interpreted as revoking old ways of life and threatening livelihoods and local culture.

Globalization also has great effect on local identities. Identity "refers to the ways in which individuals and collectivities are distinguished in their social relations with other individuals and collectivities" (Jenkins, 1996, p. 4). The identity of a nation or community is of course very important. It is a 
Hariyanti, T. (2020). Pancasila as the cultural traits for Indonesian national religious identity in the era of globalization. EduLite: Journal of English Education, Literature, and Culture, 5 (2), 359-368. DOI: http://dx.doi.org/10.30659/e.5.2.359-368

specific character that distinguishes it from other nations or communities, which at the same time reveals the personality of the nation. Therefore, maintaining identity becomes an important mission for every nation or community. When everything is globalized there will be no distinguished features, as a result there will be no specific identity. This is a serious problem and there have been some efforts to deal with it.

The interconnectedness between globalization and localism covering state, nation and community, has been attracting the attention of scholars and researchers all over the world, and lots of studies have been done with their own emphasis. Among researches and studies done is the one that emphasizes on the interconnectedness between globalization with religious identities. Some points out the negative effect of globalization on religious identity. For example, Nayestani and McInturff (2006) assert that globalization with rise of Information and Communications Technologies (ICT) can advance the destruction of existing cultures and religious identities. Other studies show the positive and challenging effect of globalization on religious identity. According to Thomson (2012) globalization has stimulated a return to old civilizations and world religions as cultural systems and imagined communities. El Azzouzi (2013) said that globalization help religions get its strength and fertile ground to spread globally. It "makes religions more conscious of themselves as being "world religions" reinforcing their respective specific identities" (2013, p. 152), yet it is challenging due to their resistance toward globalization values such as liberalism, consumerism, rationalism. Similarly, Golebiewski (2014) points out that globalization brings religions to a circle of conflicts that reinforces their specific identities, and that the relationship between religion and globalization has brought new possibilities but also furthering challenges.

Since the very beginning Indonesia has been well known as a "religious state" in which there is no separation between state and religion. Indonesia has religious diversity and 6 of them are officially recognized by the state. There is a Ministry of Religious Affairs responsible for the administration of religious affairs. The positive and negative effect of globalization will also inevitably affect religious identities in Indonesia and we need to maintain our national religious identity

Adopting the concept of grounded globalism by James L Peacock which affirms and seeks embodied connectedness to locale; this paper aims to emphasize that Pancasila is still qualified and deserve to be used as a basic foundation to maintain and strengthen the national religious identity of the Indonesian people in global era. By grounding global identity on the local context, Indonesians can enjoy globalization without losing national and regional identity. 


\section{METHOD}

This study is a library research, in the sense that the data sources come from written and digital materials related to the topic discussed, both those contained in books, articles and other data in other libraries. Data collection technique used in this study is the documentation method, which is searching for data about things or variables in the form of notes, transcripts, books, newspapers, magazines, and the results of studies and research. Documents needed in this study are documents in the form of data relating to the issues of globalization, religious identity and Pancasila. Data analysis is done by using descriptive-analysis method, which is trying to explain the topic of study and then analysed as carefully as possible to draw conclusions. The approach used is a historical approach, which is to trace the history of Pancasila as the basis of state philosophy which is expected to be a basis for reinforcement that Pancasila is capable of being a common foundation and cultural traits as well for Indonesia's national religious identity.

\section{Theoretical Background}

Focusing on the South, Peacock (2007) asserts that Globalization has the capacity to fundamentally transform the South-not only economically, demographically, and perhaps politically, but also culturally and psychologically - to create an identity at once global and regional. He proposes Grounded Globalism to secure local identity in Globalization. Globalism is deemed as the catalyst which critically energizing a configuration of process to affect deep within. Attention to the local impact is a part of grounded globalism which considers viability at all levels, from local communities to states, regions, nation, and the world (p. 237). Grounded Globalism describes and prescribes syntheses of international connections and local traditions that are fueled by energies from both. With respect to the South Peacock asserts that to ground globalism is to fuse a transformative global identity to a sustaining regional identity - a fusion that potentially enhances the strength of both identities and their potential for energizing action (p.x-x1).

It covers seven steps model which include past, present and future. Regional Identity, Opposition to national Identity, Rebellion, Defeat, and Resentment and Oppression are the first five steps intending to trace the past. Transformation by Global Identity is the sixth step which deals with the present. It proposes that a shift to a global perspective can overcome the result of past experience. Grounding of that identity in sustained regional identity is the last step intended to deal with the future. The last step is a hope for future also based on the actions of Southerners in the recent past and in the present seeks to a return of the first step - regional identity - by grounding global identity in a local context. The last two steps will be adopted to emphasize the importance of reinforcing Pancasila as the common ground and cultural traits of national religious identity of Indonesian

\section{RESULTS AND DISCUSSION}

Initially the interconnectedness between globalization and religion seemed to be ignored. When talking about globalization people tend to relate it to economic, political and socio-cultural issues. When religion begins to be 
Hariyanti, T. (2020). Pancasila as the cultural traits for Indonesian national religious identity in the era of globalization. EduLite: Journal of English Education, Literature, and Culture, 5 (2), 359-368. DOI: http://dx.doi.org/10.30659/e.5.2.359-368

associated with globalization, the study will generally be patterned into two possibilities. In the one perspective they will focus on religious responses to globalization and religious interpretations of globalization. Bayer (1994) pointed out that there are at least three forms of religious responses to the process globalization and all the effects it carries, that is being resistant, accommodating, and critical. On the other hand, religions are also deemed to have significant role in bring about and characterizing globalization. The studies usually focus on the role of religion on globalization and the effects of globalization on religions. When associated with the religious identity, globalization is often interpreted as carrying among others the values of pluralism and secularism.

\section{Pluralism}

Globalization is more precisely interpreted as a process to unite everything into a single homogeneous whole. In the process, however it creates various local identities so that diversity comes to rule more than ever before in local spaces (Lehmann, 2009). In this respect Gale (2005) pointed out that globalization encourages religious pluralism; religions identify become less rooted in particular places because of diasporas and transnational ties; and that globalization further provides fertile ground for a variety of noninstitutionalized religious manifestations and for the development of religion as a political and cultural resource.

In response to such implications, Golebiewski (2014) suggested that to have global identity, religions must use the communication easily available through advanced technology to focus more on the humane and pluralistic forms of their teachings-values such as human dignity and human freedomas means to manage religious diversity and avoid violence. In other words, religious should be open to other traditions and what they can teach. The awareness and the acknowledgment of the existence of other religions and the possibility of conflict encouraged the idea of global ethic. In 1993 A Parliament of the World's Religion issued the Declaration toward a Global ethic with four basic principles that 1) No new global order without a new global ethic!; 2) A fundamental demand: Every human being must be treated humanely; 3) Irrevocable directives consisting of Commitment to a Culture of Non-violence and Respect for Life. Commitment to a Culture of Solidarity and a Just Economic Order, and Commitment to a Culture of Tolerance and a Life of Truthfulness, and 4) A Transformation of Consciousness! The declaration is closed with an invitation for all "whether religious or not, to do the same" (1993. p. 15).

Pluralism is not a novel and strange thing for Indonesians. Living in a country consisting of thousands of islands, each of which certainly has different ethnic groups, customs, languages, religions and beliefs, the Indonesian people see diversity as natural reality. In fact, this diversity is not a barrier to forming a unitary state of Indonesia. By making "Bhinneka Tunggal Ika" which literally means diverse, but one and usually refers to "Unity in Diversity" as the State's motto it shows that the State formally recognizes the existing diversity of tribes, religions, languages, and various other aspects of culture in Indonesia. The moto is used with the aim of explaining the ideology of the Indonesian nation, Pancasila. 
The formulation of the 5 precepts in Pancasila which is known today is the result of a compromise of tolerant and open-minded founding fathers in religion and the embodiment of the values of local wisdom, customs, and cultural heritage of ancestors, because as stated by Notonagoro (1995) that Pancasila was excavated from Indonesian people since ancient times. Before Indonesian independence the elements of Pancasila were already possessed, practiced in customs, in culture in a broad sense and in the religions of the Indonesian nation.

Further Notonagoro (1995) asserted that in the diversity of conditions in ethnic groups in terms of customs, culture in a broad sense and in religious matters there are certain elements of similarity. After the Indonesian nation has pledged itself as a state, Pancasila then has another function as the principle of state. Therefore, Notonagoro argues that the Indonesian nation has "Pancasila" in the "tri-prakara" which is jointly owned and there is no contradiction between the State Pancasila, "Pancasila" culture and "Pancasila" Religion. In fact, it is mutually reinforcing.

Thus, in line with religion, Pancasila is the principle of philosophy or spirituality of the Indonesian people. Pancasila as the basis of state philosophy is recognized as an ideal model of Indonesian-style religious plurality. In the implementation, the State officially recognizes 6 religions consisting of Islam, Catholicism, Protestantism, Hinduism, Buddhism and recently Confucianism as state religions. They are different but they have the same religiosity, namely the existence of mutual recognition of the Almighty God. In addition, there are more than 150 sects (Kuswanjono, n.d.).

Historically, when traced from the history of the birth process of Pancasila, the first percept that is recognized now is the result of compromise, tolerance and open mindedness of the founding fathers over the diversity of religions that already exist in society. In the initial draft there were 7 words considered only in favor of certain religions, and replaced by neutral phrases that are considered acceptable by all adherents of the existing religions.

Pancasila, especially in the first principle, Belief in the one and only God contains among others a guarantee to the people to embrace their respective religions and worship according to their religion, not to force to any religions; to ensure the development and flourishing of religious life, and to keep religious tolerance, emphasizing in worship according to their respective religions. Article 29 of the 1945 Constitution paragraph (2) asserts, the State guarantees the independence of each resident to embrace their respective religions and to worship according to their religion and belief. Each religion has a holy book that guides the spiritual life and worldly life in society. Pancasila put the adherents of all those state religions on the equal level. There is no such term like protected minority, by the government in Indonesia. There are no such kinds of discriminations. Take it as an example. Determination of religious holidays for each formal religion is given to all religions without seeing the number of adherents. There is no idea to eliminate religious holidays for any religions that have only few numbers of adherents. It is the same with the provision of religious teachers, especially in public schools. The state provides all teachers for all religions. 
Hariyanti, T. (2020). Pancasila as the cultural traits for Indonesian national religious identity in the era of globalization. EduLite: Journal of English Education, Literature, and Culture, 5 (2), 359-368. DOI: http://dx.doi.org/10.30659/e.5.2.359-368

Culturally Indonesian people are known as people who make leaders as role models. Implicitly the religious values in the first precepts contain a moral message for all religious leaders to guide their followers to carry out all religious teachings and at the same time maintain that tolerance and mutual respect.

Indeed, the awareness of the existence of other religions will be accompanied by the awareness of the existence of distinguished identities which among others denote to certain beliefs commonly attributed the religion concerned, and referring Lehmann (2009) to a symbolic system that provides powerful emotional and meta-social mechanisms for the resolution of psychological and social tension. Tolerance and mutual respect are advisable.

Thus, Pancasila which is the spiritual basis of the Indonesian nation that had existed since before independence could be an umbrella for all religions and beliefs of the Indonesian people. Pancasila could be the ground and cultural traits of the national religious identity which is pluralistic and global.

\section{Secularism}

Globalization is also deemed to be the carrier of secularism. The root of secularism is the desire to base the knowledge and governance of society on the foundation of non-religious scientific rationality and also make it a basis for the orientation of the modern state. All of that according to Falk (2001) is closely related to efforts to limit the impact of religion on public order. Modernization and rationalization give rise to the reduction of religion's role; it would fade away or would, at least, be limited to the private sphere. There is separation between state and religion. "One way of depicting secularization in modern era is that modern culture does not necessarily encourage disbelief, but it is said to encourage rational belief, that is belief based on doctrine, on principles, on texts" (Lehmann, 2009, p. 408). Nieuwenhuis (2012), however, pointed out interesting facts that the secularization of society never has been a "global" phenomenon, and that religion remains an important factor in the social, cultural, and political domains. It turns out that religion cannot be reduced to a personal conviction, which has no meaning outside the private sphere. He gives an example that even in a secular state like Turkey which strictly separates religion with state there in still an interference of the state on religious affairs. In Turkey, the government strongly influences the appointment of imams.

In fact, there is not homogenously global secularism or theocracy. There is various model of the relation between state and religion. Winfried Brugger in Nieuwenhuis (2012) presents 6 models of the relationship between state and religion. First, the state is completely opposed to religion. Second model is characterized by a "wall of separation" not only in theory but also in practice. Third, "separation" and "allowing for" are linked. The Government may neither advance nor obstruct religion. The fourth model combines separation with some kind of cooperation. The fifth model is characterized by a more formal unity of state and church in the form of an established church. State and church still have their own different aims respectively. The state is for the citizen's welfare and the church for his salvation. In the last model that difference has disappeared, state and church actually converge in a theocracy. 
In this respect Indonesia has its own characteristic. Indonesia is not a religious state that bases all government, regulations and all its activities on a single religion but bases on Pancasila as national identity, where religious values are the basis of all other values; it is not a secular state either. Indonesia is a country that regards Pancasila as the spiritual basis of the nation. Pancasila would not lead Indonesian people to be secular. The Indonesian nation is a religious nation.

The values of Pancasila according to Notonegoro in Atmoredjo (2016) are classified in three categories: material values, vital values and spiritual values. Spiritual values are divided into 4, namely: the value of truth that comes from human reason, the value of aesthetics that comes from taste; moral values which are derived from human will and ethic, and religious values which are the highest and absolute divine and spiritual values. This religious value comes from human belief in God's power; and thus, will be the base for other values. Should all actions and thoughts be based on spiritual values, then automatically other values that lead to secularism will disappear.

The whole and unity of the Pancasila values are referred to as a value system that is believed to be a reflection of the conscience of the Indonesian people. Furthermore, Notonagoro highlighted that: 1) Pancasila as a value system has characteristics, which are the complete unity of each constituent element; and the elements are absolute, cannot be added or reduced. 2) The composition of the Pancasila precepts is organic unity, forming each other a system called "single compound." This means that Pancasila consists of 5 precepts but it is a unified whole. Likewise, Hatta (1977) asserted that the five principles are a series that is inseparable from one another. Under the guidance of the first principle, Belief in the one and only God, the five principles are bound.

The first principle of Pancasila is Belief in the one and only God which reflects the belief of the Indonesian nation of the existence in the Almighty God, the Creator of the universe as a whole. The first precept is the main source of the values of the Indonesian nation's life, animates and underlies and guides the realization of civilized humanity, the raiser of Indonesian Unity which has formed a sovereign, populist Republic of Indonesia which is led by wisdom in deliberation in order to realize social justice for all Indonesian people. This means that the implementation of the whole principles should be based on Indonesian belief in the Almighty God. It is not recommended to implement separately.

Implementation of the integration of Pancasila values based on religious values is seen in some examples. In the history of the formulation of Pancasila itself it is known that there were 3 formulations of Pancasila submitted by Muhammad Yamin, Dr. Soepomo and Ir. Soekarno, the three of them, suggested the Divine Precepts that shows their religiosity. At the same time a mutual agreement to later establish the formulation of the principles of Pancasila as it is known today shows the value of unity and deliberation.

Another example of Indonesian religiosity can be seen clearly in important documents such as in the Preamble to the 1945 Constitution which says "Blessed by God the Almighty and impelled by noble desires for a free 
Hariyanti, T. (2020). Pancasila as the cultural traits for Indonesian national religious identity in the era of globalization. EduLite: Journal of English Education, Literature, and Culture, 5 (2), 359-368.

national life ... (Simonangkir \& Say, 1980, p. 9) and in Decree of the President of July 5, 1959 which is started with : "With the Blessing of the One Supreme God We, The President of The Republic of Indonesia...(Simonangkir \& Say, 1980, p. 3)."

The actualization of the values of Pancasila done by the Indonesian people is also obviously reflected in the way they socialize in their daily lives. In their every action without distinguishing religion it has become their habit to always begin and end with prayer. Mutual respect and religious tolerance will be seen more clearly in activities involving people of different religions. The prayer leader will invite each to pray according to his beliefs. The places of worship of each religion are almost always found in every corner of villages and cities and each of his followers can carry out their worship rituals freely and safely. Major celebrations in each religion can also be held by followers without interference from the followers of other religions. Even the facts show that certain religious celebrations can be followed and enjoyed by followers of other religions. They assume that as long as they keep their beliefs and as long as they do not follow their religious rituals, they can participate in celebrating such as celebrating Eid al-Fitr and Eid al-Adha. If cultural and religious life in Indonesian society that reflects the values of Pancasila is maintained, then secularism is not a threat to national religious identity

\section{CONCLUSION}

As a conclusion, it is not necessary for Indonesia to succumb to the force of globalization and transform its national religious identity to the global identity. Indonesia has already had its own national identity which is absolutely global. Pancasila deserves to be the common ground and be the cultural traits for Indonesia national religious identity, because Pancasila guarantees religious diversity and harmonious religious relations; and Pancasila values can counteract the flow of secularism. The best way to respond to the force of globalization is by reinforcing the existing identity and actualizing the values of Pancasila in the life of the nation and state and in relation to other nations regionally, nationally and internationally.

It is also necessary to recall that one of the backgrounds of the Proclamation of Independence is the emphasis that the people of Indonesia who are multi-ethnic-religious-group, live in harmony in an atmosphere of unity, which also stands equally harmoniously with other nations in the world, in a world order that upholds the principle of equality and values noble human values. 


\section{REFERENCES}

Atmoredjo, S. (2016). Ideologi Hukum Indonesia: Kajian tentang Pancasila dalam Perspektif Ilmu Hukum dan Dasar Negara Indonesia. Yogyakarta: Lingkar Mulia.

Azzouzi, M E1. (2013) "Religion and Globalization: Benefits and Challenges," Romanian Review of Political Science and International Relations 10, pp.150-154.

Beyer, P. (1994). Religion and Globalization. London: Sage Publication

"Declaration Toward a Global Ethic," (1993). Council for a Parliament of the World's Religions, Chicago.

Falk, R. (2001). Secularism in an Era of Globalization. In: Religion and Humane Global Governance. Palgrave Macmillan, New York DOI: https://doi.org/10.1007/978-1-349-62975-6_3

Gale, T. (2005). "Globalization and Religion." Encyclopedia of Religion. Retrieved September 06, 2018 from Encyclopedia.com: http://www.encyclopedia.com/environment/encyclopedias-almanacstranscripts-and-maps/globalization-and-religion.

Golebiewski, D1. (2014). Religion and Globalization: New Possibilities, Furthering Challenges. Available at: https://www.eir.info/2014/07/16/religion-and-globalization-new-possibilitiesfurthering-challenges/retrieved September 2018.

Hatta, M. (1977). Pengertian Pancasila. Jakarta: Idyu Press .

Jenkins, R. (1996). Social Identity. London: Routledge

Kuswanjono, A. (n.d.). Pluralisme Pancasila. Retrieved from https://crcs.ugm.ac.id/pluralisme-pancasila/

Lehmann, D. (2009). Religion and globalization www.davidlehmann.org /.../Religion\%20and\%20Globalizatio...

Neyestani, M R., \& McInturff, P. (2006). "Cultural and Religious Identities in an Era of Information and Communications Globalization," Communications of the IIMA: Vol. 6: Iss. 4, Article 8. Available at: http://scholarworks.lib.csusb.edu/ciima/vol6/iss4/8

Nieuwenhuis, A J. (2012). "State and religion, a multidimensional relationship: Some comparative law remarks". International Journal of Constitutional Law, 10(1), pp.153-174, https://doi.org/10.1093/icon/mos001

Notonagoro (1995). Pancasila Secara Ilmiah Populer. Jakarta: Bumi Aksara.

Peacock, J L. (2007). Grounded Globalism: How the U.S.South Embraces the World. USA: The University of Georgia Press.

Simonangkir,J.C.T \& Say,BMR. (1980). Around and About the Indonesian Constitution of 1945. (J. Achyadi, Trans). Jakarta: Djambatan. (Original Work published in 1974). 
Hariyanti, T. (2020). Pancasila as the cultural traits for Indonesian national religious identity in the era of globalization. EduLite: Journal of English Education, Literature, and Culture, 5 (2), 359-368.

DOI: http://dx.doi.org/10.30659/e.5.2.359-368

Thompson, K. (2012). Globalization and Religion in the Oxford Handbook of Cultural Sociology. Edited by Jeffrey C. Alexander, Ronald N. Jacobs, and Philip Smith. Oxford Handbooks.htm. DOI: https://doi.org/10.1093/oxfordhb/9780195377767.013.1 